\title{
A low molecular weight factor is a significant mediator of non-opsonic neutrophil activation by Helicobacter pylori
}

\author{
ALISON LEAKEY*†, ROBERT HIRST* and JUSTIN LA BROOY† \\ * Department of Microbiology and Immunology, James Cook University and †Department of Medicine, North \\ Queensland Clinical School, University of Queensland, Australia
}

\begin{abstract}
Helicobacter pylori is believed to trigger neutrophil activation through several factors, including the $\mathrm{H}$. pylori neutrophil-activating protein (HpNAP). The aim of this study was to characterise the factors within $H$. pylori cell-free extracts that stimulate neutrophil activation. Neutrophil activation was found to be dose-dependent and exhibited considerable variation between different clinical isolates. Activity was attributable to more than one protein factor. A low mol. wt fraction of $<3 \mathrm{kDa}$ was found to contribute a large proportion of the neutrophil-stimulating activity within $\boldsymbol{H}$. pylori cell-free extract. Additional activity was provided by a high mol. wt fraction, possibly representing HpNAP. An inhibition ELISA and neutralisation experiments failed to identify or exclude formyl methionyl leucyl phenylalanine as the active factor within the low mol. wt fraction. The importance of the putative, low mol. wt neutrophil-activating factor may have been overlooked by those studies that have used concentrated $H$. pylori extracts.
\end{abstract}

\section{Introduction}

The pathogenesis of peptic ulcer disease (PUD) is multifactorial and includes the dual damage caused by reactive oxygen intermediates (ROI) released by activated neutrophils and the action of the Helicobacter pylori vacuolating cytotoxin on the gastric epithelium. However, not all $H$. pylori isolates stimulate the production of ROI from neutrophils in vitro [1-4]. Similarly, only a subset of $H$. pylori isolates express vacuolating cytotoxin activity [5-7]. Together and independently, these characteristics have been found to be associated with the development of PUD [1-4, 8-11].

A previous study found that the ability to activate neutrophils and vacuolating cytotoxin activity are found more frequently in $H$. pylori isolates from patients with PUD than in patients without ulceration [12]. Through the action of the vacuolating cytotoxin, the gastric epithelium may become more permeable to the passage

Received 8 Nov. 2000; revised version accepted 20 Feb. 2001.

Corresponding author: Dr A. Leakey (e-mail: alisonleakey@) hotmail.com).

Present address: Laboratory of Respiratory and Special Pathogens Center for Biologics Evaluation and Research, FDA, 8800 Rockville Pike, MD 20892, USA. of $H$. pylori neutrophil-activating factors, increasing the susceptibility of the lower tissue layers to the deleterious effects of ROI.

Previous studies have attempted to characterise the neutrophil-activating and chemo-attractive factors present in $H$. pylori extracts [13-18]. However, different research groups have reported factors with disparate mol. wts and activities. As a result, the size and nature of $H$. pylori activating and chemo-attractive factors remain unclear. Some authors have reported activating and chemo-attractive factors to be heat-labile [18, 19], in contrast to others who have found activating factors to be resistant to the effects of high temperature $[14,16]$. Nonetheless, neutrophil-activating and attractant factors in $H$. pylori extracts have been concluded generally to be primarily proteinaceous, with additional possible activity originating from non-protein components including lipopolysaccharide (LPS) [18, 20], despite the fact that $H$. pylori LPS is thought to be of low biological activity [21].

Several proteins with neutrophil-activating and chemoattractive properties have been identified in $H$. pylori extracts. The H. pylori urease protein may display chemo-attractive activity [15], as have uncharacterised $25-35-\mathrm{kDa}$ and $10.5-\mathrm{kDa}$ proteins $[16,17]$. The same 25-35-kDa chemo-attractant protein described by 
Nielsen and Andersen (1992) was also shown to activate neutrophils [16]. However, the best described of all the $H$. pylori neutrophil-activating proteins is the H. pylori neutrophil-activating protein (HpNAP). In its native form, HpNAP is a $150-\mathrm{kDa}$ homodecamer of 15 $\mathrm{kDa}$ subunits [22, 23].

Several groups have observed a low mol. wt activating and chemo-attractant factor in $H$. pylori sonicates and conditioned media $[13,14,18]$. However, conclusions regarding the exact size and nature of the low mol. wt $H$. pylori neutrophil-activating factor have varied. Mooney and associates attributed activating properties in $H$. pylori extracts to chemotactic formylated peptides and found activity to elute in the same fraction as commercially available formyl methionyl leucyl phenylalanine (fMLP) [13]. This fraction and that from several intestinal bacteria also appeared to be antigenically cross-reactive with fMLP $[13,24]$. In contrast, activity was concluded by others to be distinct from bacterial formylated peptides $[15,18]$. This study addressed these contradictory findings.

\section{Materials and methods}

\section{Source and culture of $H$. pylori strains}

The two H. pylori strains chosen for this study were selected from a bank of 46 isolates that were originally cultured from gastric biopsy specimens, collected at endoscopy from patients in several hospitals in North Queensland, Australia. The identification and culture of these isolates has been described previously [12].

Strain 96T/KAD was isolated from a patient with endoscopically observed peptic ulcer. This strain produced cytotoxin, but was $\operatorname{cag} A(-)$. Strain 96T/PRI was also obtained from a patient with PUD, was $\operatorname{cag} A(+)$, but did not produce cytotoxin. Strain 96T/ KAD had previously been found to activate neutrophils, whereas strain 96T/PRI did not [12]. The measurement of vacuolating cytotoxin activity and the ability to activate neutrophils has been described previously [12]. The $\operatorname{cag} A$ gene was detected in isolates by the method described by Weel and colleagues [11].

\section{Measurement of neutrophil activation}

Two methods were used to measure neutrophil activation, a luminol-enhanced chemiluminescent (LEC) assay and a flow cytometric assay based on the oxidation of dihydrorhodamine-123 (DHR). The LEC assay provided a convenient method of monitoring neutrophil activation over a period of time, yielding measures of ROI release at regular intervals from the same samples. In contrast, the DHR assay provided one measure per sample, but was advantageous because of consistently low levels of background activation in negatively controlled samples.
LEC assay. Neutrophils were purified from whole blood collected from one adult volunteer by density gradient centrifugation. Two-ml volumes of whole blood were layered on to 2-ml volumes of Histopaque (Sigma) before centrifugation $(1000 \mathrm{~g}$ for $15 \mathrm{~min}$ at $\left.15^{\circ} \mathrm{C}\right)$. The neutrophil-erythrocyte plug was then obtained. Erythrocytes were lysed for $10 \mathrm{~min}$ in $10 \mathrm{ml}$ of lysis buffer that had been pre-warmed to $37^{\circ} \mathrm{C}$. Leucocytes were centrifuged $(400 \mathrm{~g}$ for $5 \mathrm{~min}$ at room temperature), washed and resuspended in $1 \mathrm{ml}$ of Hanks's Balanced Salts Solution (HBSS) + EDTA (Sigma). The resultant neutrophil population $\left(1 \times 10^{6} / \mathrm{ml}\right)$ was added to the chemiluminescent substrate 5-amino-2,3-dihydro-1,4-phthalazinedione (Luminol; Sigma) at $1 \times 10^{-5} \mathrm{M}$ in HBSS + EDTA to achieve a final suspension of $5 \times 10^{5}$ neutrophils $/ \mathrm{ml}$.

This preparation was dispensed as $180-\mu 1$ volumes into black 96-well plates (Fluoroplates, Flow Laboratories, Finland), to which $20-\mu$ l test samples were added. Buffer only was added to other samples as negative controls and phorbol myristate acetate (PMA; Sigma) $40 \mathrm{ng}$ and fMLP (Sigma) $1 \mu \mathrm{g}$, were used as positive stimuli of ROI release. A Packard TopCount Luminometer set to single photon count (SPC) mode was used to measure the emission of light at $25^{\circ} \mathrm{C}$ for 90 min following the addition of samples.

DHR flow cytometric assay. Samples of whole blood $(100-\mu \mathrm{l})$ were lysed in $4 \mathrm{ml}$ of pre-warmed $\left(37^{\circ} \mathrm{C}\right)$ lysis buffer for $5 \mathrm{~min}$ to destroy erythrocytes. After centrifugation at $400 \mathrm{~g}$ for $3 \mathrm{~min}$ at room temperature, leucocytes were washed and resuspended in $400 \mu \mathrm{l}$ of suspension buffer. DHR-123 (Molecular Probes, Eugene, OR, USA) was added to a final concentration of $1 \times 10^{5} \mathrm{nM}$ and incubated for $5 \mathrm{~min}$ at $37^{\circ} \mathrm{C}$. Suspension buffer, PMA $40 \mathrm{ng}$, fMLP $1 \mu \mathrm{g}$ or $H$. pylori cellfree extract $100 \mu \mathrm{g}$ was added to triplicate tubes unless otherwise stated. Samples were incubated for a further $30 \mathrm{~min}$ at $37^{\circ} \mathrm{C}$ before immediate flow cytometric analysis with a Becton Dickinson FACScan Flow Cytometer.

\section{Fractionation of active factors in the cell-free extracts of $H$. pylori by ammonium sulphate precipitation}

Ammonium sulphate (Sigma) cuts of $0-40 \%, 40-60 \%$, $60-80 \%$ and $80 \%+$ were prepared from cell-free extracts of strain $96 \mathrm{~T} / \mathrm{KAD}$. At each stage, the mixtures were centrifuged at $10000 \mathrm{~g}$ for $10 \mathrm{~min}$ at $4^{\circ} \mathrm{C}$. Pellets were resuspended in $\mathrm{ddH}_{2} \mathrm{O}$ before passage through desalting HiTrap columns (Pharmacia Biotech, Uppsala, Sweden). The $80+\%$ fraction, which represented the constituents of the cell-free extract that could not be precipitated by an $80 \%$ ammonium sulphate cut, was similarly desalted. Samples of $100 \mu \mathrm{g} / 20 \mu \mathrm{l}$ of each precipitated fraction were used to stimulate neutrophils. Neutrophil ROI release was measured by the LEC assay. 
Fractionation of the activating factors within $H$. pylori cell-free extract by gel filtration column chromatography

H. pylori cell-free extract $(20 \mathrm{mg}$ at $5 \mathrm{mg} / \mathrm{ml})$ was treated with $1 \mathrm{mM}$ phenylmethylsulphonyl fluoride (PMSF) and concentrated four-fold with UltraFree Biomax-5000 MW cut-off filters (Millipore, Bedford, MA, USA). The supernate $(>3 \mathrm{kDa})$ and filtrate $(\alpha$ fraction, $<3 \mathrm{kDa}$ ) were collected. Proteins in the supernate were separated on the basis of size by gel filtration with a Sephadex G-100 (Pharmacia Biotech), $300 \times 16 \mathrm{~mm}$ column $(1 \mathrm{ml}$ sample; $0.6 \mathrm{ml} / \mathrm{min}$ in PBS + EDTA, pH 7.2; $5.5 \mathrm{ml}$ fractions) and a GradiFrac $^{\mathrm{TM}}$ Chromatography System (Pharmacia Biotech). The column had previously been calibrated with blue dextran $(2000 \mathrm{kDa})$, catalase from bovine liver (BC, $232 \mathrm{kDa}$ ), bovine albumin fraction $\mathrm{V}$ (BSA, Sigma; $67 \mathrm{kDa}$ ), cytochrome $c$ from horse heart $(12 \mathrm{kDa})$ and phenol red $(300 \mathrm{Da})$. All mol. wt standards were obtained from Sigma.

After separation, column fractions were concentrated by $60 \%$ ammonium sulphate precipitation, resuspended in suspension buffer and desalted with HiTrap columns (Pharmacia Biotech). The resultant fractions were assayed for neutrophil-stimulating activity in the LEC assay after adjustment to a protein concentration of $100 \mu \mathrm{g} / 20 \mu \mathrm{l}$.

\section{Characterisation of the low mol. wt a fraction with anti-fMLP mouse serum}

To investigate the nature of active components within the $\alpha$ fraction, an antiserum was prepared against commercial fMLP for use in ELISA and neutralisation experiments.

Conjugation of fMLP to protein carriers. Commercially available fMLP (Sigma) was conjugated via the $\mathrm{C}$ terminus to BSA or keyhole limpet haemocyanin (KLH; Sigma) by the carbodiimide reaction. Ten $\mathrm{mg}$ of 1-ethyl-3-(3-dimethylamino-propyl) carbodiimide (ED $\mathrm{AC}$; Sigma) were dissolved in $20 \mathrm{ml}$ of $\mathrm{ddH}_{2} \mathrm{O}$. Then $5 \mathrm{mg}$ of fMLP, reconstituted in DMSO (Sigma), were added and the reaction was allowed to proceed for $5 \mathrm{~min}$ at room temperature. After the addition of $7.5 \mathrm{mg}$ of the protein carrier, the reaction was incubated at $4^{\circ} \mathrm{C}$ overnight. Dialysis with a 10000 mol.wt cut-off membrane (Millipore) was performed overnight against $\mathrm{ddH}_{2} \mathrm{O}$ before drying down to onetenth of volume overnight in a fume cupboard.

Antiserum production. Half of the fMLP-BSA conjugate preparation was emulsified in an equal volume of Freund's complete adjuvant (FCA; Sigma) before subcutaneous injection as $200-\mu 1$ volumes into five 6week-old male BALB/c mice. Then, 14 days later, boosting injections of $200 \mu \mathrm{l}$ of the same preparation emulsified in Freund's incomplete adjuvant (FIA;
Sigma) were given intraperitoneally. After 10 days, animals were killed with $\mathrm{CO}_{2}$ and the total blood volume was obtained immediately, following dissection of the carotid artery. Serum was separated, heatinactivated $\left(56^{\circ} \mathrm{C}\right.$ for $\left.30 \mathrm{~min}\right)$ and stored in divided volumes at $-70^{\circ} \mathrm{C}$. All five animals had generated similar antibody titres when tested against a reciprocal fMLP-KLH conjugate (mouse 1, 500; 2, 500; 3, 500; 4, $400 ; 5,500)$.

Mice were housed at the Small Animal Experimental Facility at James Cook University and were provided with water and dried, pelleted food ad libitum. Ethical approval for antiserum production was obtained from the James Cook University Experimental Ethics Review Committee.

Inhibition ELISA for the detection of fMLP in clinical isolates of $H$. pylori. Volumes $(100 \mu \mathrm{l})$ of a 1 in 8 dilution of fMLP-KLH conjugate in PBS (final concentration $5 \mu \mathrm{g} / 100 \mu \mathrm{l}$ ) were used to coat 96-well plates (Nunclon, Nunc, Denmark) at $4^{\circ} \mathrm{C}$ overnight. Anti-fMLP-BSA polyclonal antiserum, diluted 1 in 100 in PBS-T-G, was combined with variable concentrations of competitive antigen $(10 \mu \mathrm{g}, 1 \mu \mathrm{g}, 100 \mathrm{ng}$, $50 \mathrm{ng}$ of fMLP or $\alpha$ fraction) and added to plates in a total volume of $100 \mu \mathrm{l}$ before incubation for $1 \mathrm{~h}$ at $37^{\circ} \mathrm{C}$. After washing $(3 \times 10 \mathrm{~min}$ in PBS-T), $100 \mu \mathrm{l}$ of a 1 in 2000 dilution of goat anti-mouse horseradish peroxidase (HRP) conjugate (BioRad Laboratories, Hercules, CA, USA) were added and plates were incubated for a further $1 \mathrm{~h}$ at $37^{\circ} \mathrm{C}$ before washing and colour development with 2,2'-azino-bis(3-ethylbenzthiazoline-6-sulphonic acid) (ABTS; Sigma) solution. Absorbance at $405 \mathrm{~nm}$ was measured with an LP400 SANOFI plate reader (Pasteur Diagnostics, Marnes-laCoquette, France). Dilutions of coating antigen, primary antiserum and secondary antibody conjugate had been optimised previously by a checkerboard titration. Therefore, the amount of fMLP present in the test sample was directly related to the degree of inhibition of primary antibody binding to the fMLPKLH conjugate and was measured by a decrease in colour development.

Neutralisation of neutrophil-stimulating activity in the $\alpha$ fraction. Twenty- $\mu$ l samples of the $\alpha$ fraction and $1 \mu \mathrm{g} / 20 \mu \mathrm{l}$ and $100 \mathrm{ng} / 20 \mu \mathrm{l}$ quantities of commercially available fMLP were incubated in triplicate with equal volumes of a 1 in 10 dilution of the anti-fMLPBSA antiserum described above. Following incubation for $30 \mathrm{~min}$ at $37^{\circ} \mathrm{C}$, these samples were assayed for neutrophil-stimulating activity by the DHR assay.

\section{Statistical analysis}

Statistical analyses were performed with one-way ANOVA models and the SPSS Statistical Program. 


\section{Results}

Effect of H. pylori cell-free extract concentration, temperature and protease activity on neutrophil activation

To examine the effect of concentration upon the activation of neutrophils by $H$. pylori extract, stimulation experiments were performed with two strains of $H$. pylori over a range of concentrations of the cell-free extract. A neutrophil-activating strain (96T/KAD) and a non-activating strain (96T/ PRI) were chosen from a group of isolates characterised previously [12]. The cell-free extracts of these strains were added in triplicate to chemiluminescent suspensions in $20-\mu \mathrm{l}$ volumes containing $100 \mu \mathrm{g}, 50 \mu \mathrm{g}, 10 \mu \mathrm{g}$ or $1 \mu \mathrm{g}$ of total protein. The effect of concentration on the activation of neutrophils by $H$. pylori cell-free extract was also measured by the DHR assay. Neutrophils were stimulated by the addition of $100 \mu \mathrm{g}, 50 \mu \mathrm{g}$ or $10 \mu \mathrm{g}$ of $H$. pylori cell-free extract (strain 96T/ $\mathrm{KAD)}$ or buffer only.

Neutrophil activation by cell-free extracts of $H$. pylori was found to be concentration-dependent. Strain 96T/ KAD stimulated $\mathrm{H}_{2} \mathrm{O}_{2}$ release in response to 100,50 and $10 \mu \mathrm{g}$ of extract in a dose-dependent manner (Fig. 1). In comparison, strain 96T/PRI only caused activation after the addition of $100 \mu \mathrm{g}$ of cell-free extract (Fig. 1); $100 \mu \mathrm{g}$ of strain 96T/PRI extract stimulated neutrophils to a similar degree to $10 \mu \mathrm{g}$ of strain $96 \mathrm{~T} /$ KAD extract.

When the effect of cell-free extract concentration on neutrophil activation was examined by the DHR assay, stimulation indices increased with increasing concentrations of $H$. pylori cell-free extract $\left(\mathrm{F}_{(1,3)}=81.3802\right.$, $\mathrm{p}=0.029)$ (Fig. 2).



Fig. 1. Neutrophil activation by cell-free extracts of H. pylori: $\square-\mathbf{\square}$, strain 96T/KAD $100 \mu \mathrm{g} ; \boldsymbol{\Delta} \longrightarrow \mathbf{\Lambda}$, strain 96T/

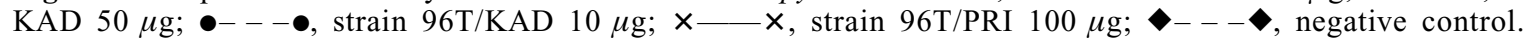

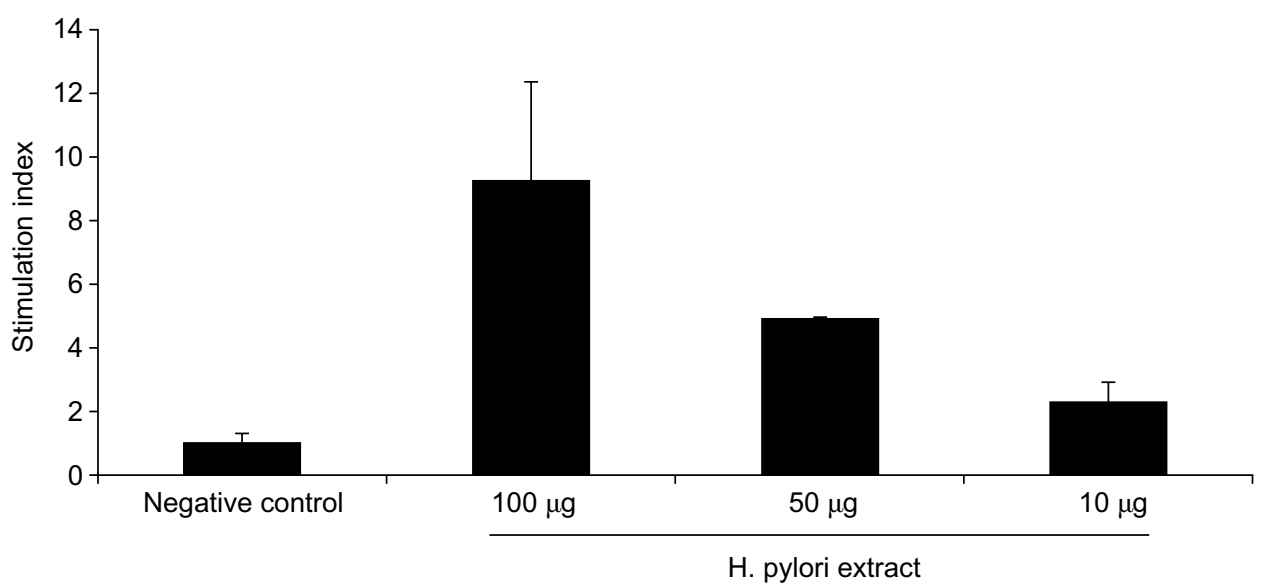

Fig. 2. Concentration-dependent neutrophil activation by H. pylori $96 \mathrm{~T} / \mathrm{KAD}$ extract in the DHR assay. Bar $=\mathrm{SD}$. 
To determine the effect of temperature and protease activity on $H$. pylori extract activity, triplicate extracts of strain $96 \mathrm{~T} / \mathrm{KAD}$ were incubated with or without the protease inhibitor PMSF at $4^{\circ}, 24^{\circ}, 37^{\circ}$ and $65^{\circ} \mathrm{C}$ for $30 \mathrm{~min}$. PMSF was dissolved in acetone at $1 \mathrm{M}$ $(0.1742 \mathrm{~g} / \mathrm{ml})$ concentration and dispersed into the cell-free extract as a 1 in 1000 dilution before incubation. After incubation, $100 \mu \mathrm{g} / 20 \mu \mathrm{l}$ of sample was added to the neutrophil suspensions and activation was measured by the LEC and DHR assays.

The factors in H. pylori cell-free extract that stimulate neutrophil activation were found to be sensitive to heat and protease. A significant decrease in activity was observed after incubation of the strain 96T/KAD cellfree extract at $65^{\circ} \mathrm{C}$ for $30 \mathrm{~min}$, in comparison with the same extract incubated at physiological temperature $\left(F_{(1,2)}=2763.7226, p=0.0004\right)$. Pre-treatment with PMSF partially prevented this loss $\left(\mathrm{F}_{(1,1)}=598.2411\right.$, $\mathrm{p}=0.0260$ ), indicating that the observed reduction in activity following incubation at $65^{\circ} \mathrm{C}$ was partially due to the action of proteases on the active factors within the cell-free extract (Fig. 3). In the DHR assay, a stimulation index of $9.058 \mathrm{SD} 0.528$ in response to $100 \mu \mathrm{g}$ of cell-free extract of strain 96T/KAD was decreased to $3.323 \mathrm{SD} 1.087$ following incubation at $65^{\circ} \mathrm{C}$ for $30 \mathrm{~min}\left(\mathrm{~F}_{(1,3)}=45.3201, \mathrm{p}=0.0067\right)$.

\section{Activity within fractionated $H$. pylori cell-free extracts}

Neutrophil-stimulating activity was found in many fractions of the $H$. pylori cell-free extract after separation on a Sephadex G-100 column. However, the column fraction that contained most activity was that expected to contain the HpNAP homodecamer $\left(10^{3}-10^{2} \mathrm{kDa}\right)$. A large proportion of the activity was also found in the low mol. wt $(<3 \mathrm{kDa}) \alpha$ fraction (Fig. 4).

When column fractions were analysed by SDS-PAGE and were stained with Coomassie Brilliant Blue and silver, multiple protein bands were observed in each fraction, with the exception of the $\alpha$ fraction (Fig. 5). Neutrophil-stimulating activity in $H$. pylori cell-free extracts was distributed evenly between the $0-40 \%$ and $40-60 \%$ ammonium sulphate precipitated fractions. Minimal activity remained in the $60-80 \%$ and $80+\%$ fractions. Attempts were made to investigate the doseresponse to the $\alpha$ fraction. When the $\alpha$ fraction was diluted $50 \%$ in buffer, $<15 \%$ of activity remained detectable. Further dilution produced negligible activity. Efforts to concentrate the activity within the $\alpha$ fraction were unsuccessful.

An inhibition ELISA was found to be capable of measuring synthetic fMLP concentrations of between $10 \mu \mathrm{g}$ and $100 \mathrm{ng} / 50 \mu \mathrm{l}$. No measurable inhibition of antibody binding in response to cell-free extract of $H$. pylori was observed $\left(\mathrm{F}_{(1,3)}=0.454, \mathrm{p}=0.8449\right)$. No significant neutralisation of activity was found when the $\alpha$ fraction was pre-incubated with anti-fMLP-BSA mouse antiserum for $30 \mathrm{~min}\left(\mathrm{~F}_{(1,4)}=0.0000, \mathrm{p}=\right.$ 0.9971). Also, similar incubation of various concentrations of fMLP with the antiserum did not result in a decrease in neutrophil-stimulating activity. For example, there was no significant difference in the activity of $1 \mu \mathrm{g}$ of fMLP and the same fMLP concentration preincubated with antiserum $\left(\mathrm{F}_{(1,3)}=0.1281, \mathrm{p}=0.7441\right)$.

\section{Discussion}

From the results of this study, it would appear that the majority of activity in $H$. pylori extracts is attributable



Fig. 3. Heat and protease sensitivity of $H$. pylori neutrophil-stimulating activity: $\mathbf{-}---\mathbf{m}$, incubation at $37^{\circ} \mathrm{C} ; \times---$ $\times$, incubation at $65^{\circ} \mathrm{C} ; \boldsymbol{\Lambda}-\mathbf{\Delta}$, incubation at $65^{\circ} \mathrm{C}$ in the presence of PMSF; 


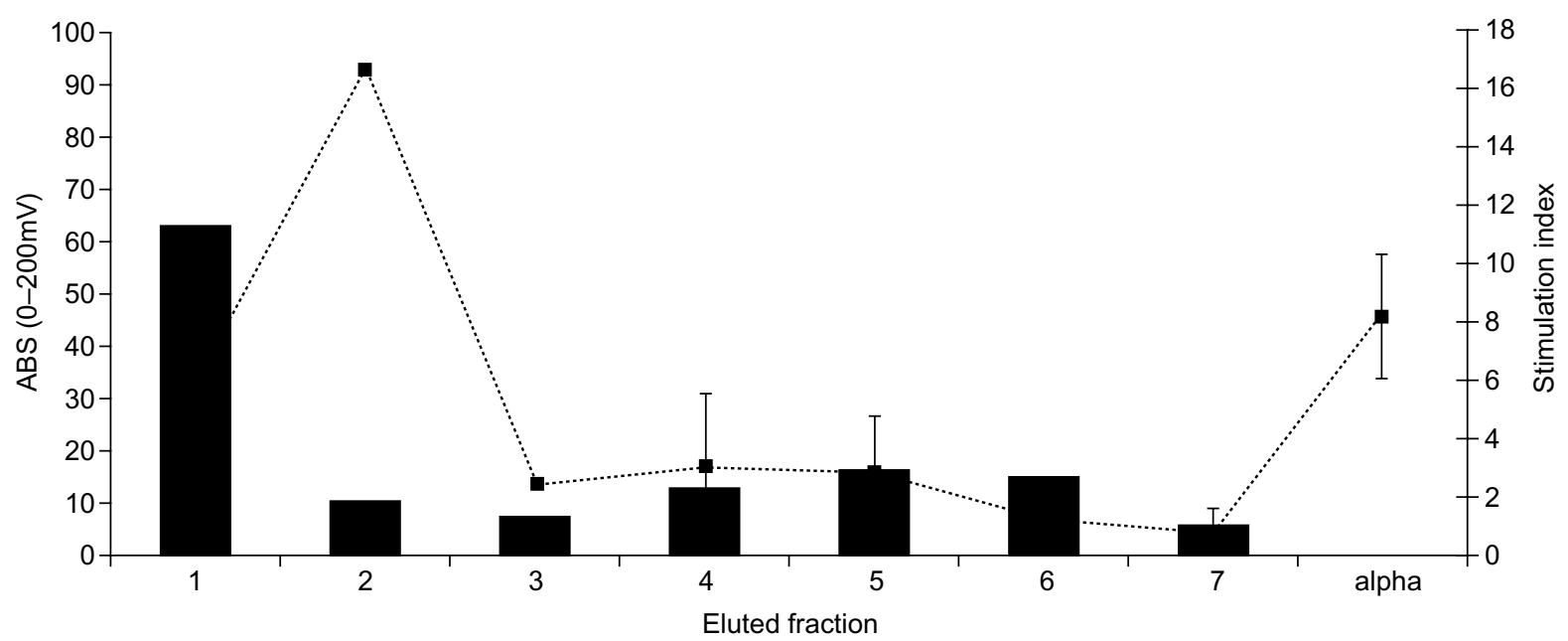

Fig. 4. Fractionation of $H$. pylori 96T/KAD neutrophil-activating factors by gel filtration. Bar graph represents protein elution, line graph represents the fractionation of activity, as measured by the DHR assay. Bar $=\mathrm{SD}$.

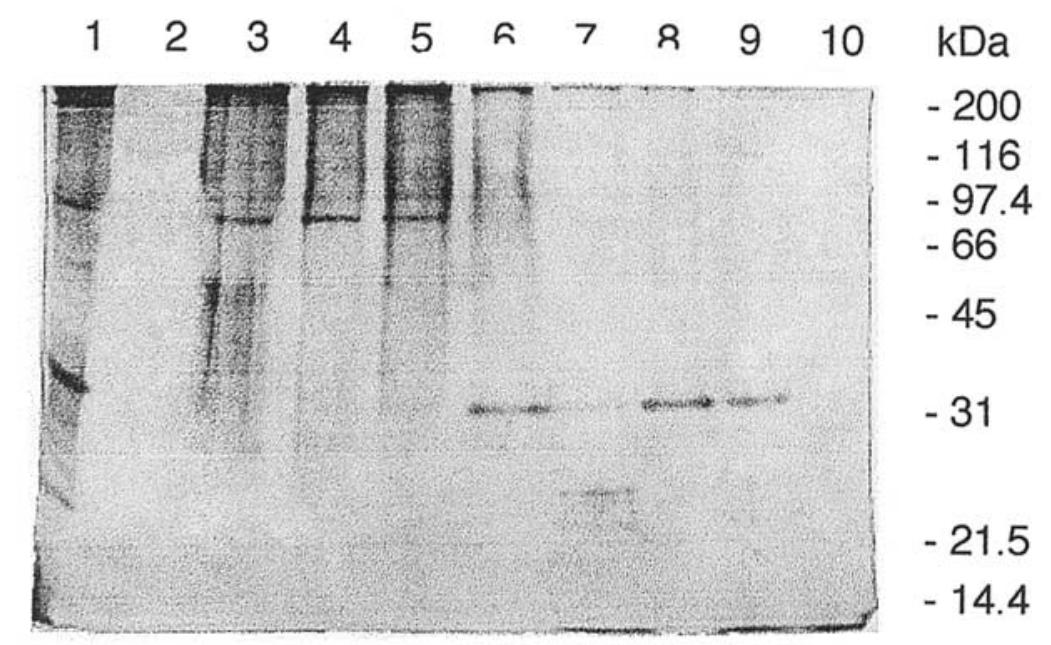

Fig. 5. Silver stain of fractions from Sephadex-G100 column. Lane 1, neat $H$. pylori extract; 2, blank; 3-9, fractions $1-7 ; 10, \alpha$ fraction.

to protein factors. LPS may contribute to some background activation but is unlikely to be of significance due to low biological activity [21]. Neutrophil activation in response to $H$. pylori extracts was found to be dose-dependent. The peak ROI release in response to high concentrations was found to occur earlier than at lower concentrations. Nielsen and Andersen also found activation to be dose-dependent $[2,16]$.

Neutrophil activation in response to $H$. pylori cell-free extracts was not immediately apparent and maximum ROI release typically took up to $30 \mathrm{~min}$ to occur when the LEC assay was used. Activation by fMLP was similarly delayed, unlike PMA activation, which is thought to bypass cell-surface receptors [25]. The delay in response to $H$. pylori cell-free extract is suggestive of activation via a receptor-mediated process.

The results described in this study were found to be consistent in both the LEC and DHR flow cytometric assays. While a non-activating strain of $H$. pylori (96T/ PRI) was found to stimulate ROI release only at high concentrations, the extract from a highly activating strain was active even at low concentrations. These results may reflect different concentrations of active factors within the extracts of the strains in question or, alternatively, differences in the specific activities of those factors.

The fractionation of active factors by gel filtration revealed that many constituents of the $H$. pylori cellfree extract were able to activate neutrophils if added in sufficient concentrations. Significant levels of activity in $H$. pylori cell-free extract were found to be attributable to factors of $10^{3}-10^{2} \mathrm{kDa}$, possibly representing the homodecamer of HpNAP. Multimers of the $15-\mathrm{kDa}$ subunit may contribute to the low levels of activity found at other mol. wts. Evans et al. reported possible additional HpNAP cross-reactive bands by Western blotting [22]. In contrast to other studies, there 
was no evidence of strong activity associated with the $61-\mathrm{kDa}$ urease subunit [15] or unknown $25-35-\mathrm{kDa}$ [16] and 10.5-kDa [17] proteins. Differences in the preparation of extracts may account for these findings.

Most activity was found to be attributable to a factor found within the low mol. wt $\alpha$ fraction. This factor, with a mol. wt of $<3 \mathrm{kDa}$, may represent fMLP or some other small peptide. The activity within similar fractions of $H$. pylori has been attributed previously to formylated peptides $[13,14]$. Other studies have used concentrated protein extracts for activation [15]. These techniques may have biased characterisation towards factors of higher mol. wt and the importance of small elements may have been discounted as a result.

Characterisation of a neutrophil-activating factor within the $\alpha$ fraction was made more difficult by its low mol. wt. Small peptides do not bind to membranes or plastic surfaces and quickly diffuse into electrophoresis gels [26]. Some peptides cannot be stained by either Coomassie Brilliant Blue or silver due to the absence of crucial amino acid residues and are present at such low levels within bacterial extracts [27] that concentration is required before electrophoresis can be performed. Ammonium sulphate precipitation was not successful in concentrating activity within extracts; significant activity was lost when this process was used. This may be due to the failure of ammonium sulphate to precipitate the active factor due to low mol. wt. Furthermore, when the $\alpha$ fraction was diluted more than twice, this process was found to result in a loss of activity and may indicate the sensitivity of the active factor once isolated from other extract proteins.

The possibility that the active factor within the low mol. wt $\alpha$ fraction was due to formylated peptides was investigated in some detail. As has been described previously in studies of formylated peptides, large volumes are required to provide sufficient material for purification and subsequent analysis [28, 29]. Other studies have used antibodies for immunoassays and neutralisation experiments [20,24]. However, these approaches, including HPLC and sequencing (results not shown), all ultimately proved to be unsuccessful when applied to the $\alpha$ fraction. As a result, it was not possible to include or exclude a formylated peptide as the active factor within $H$. pylori extracts.

Lastly, the loss of activity in fractions following purification may be influenced by the separation of active factors from other proteins. Neutrophil activation and vacuolating cytotoxin activity have been demonstrated not only to be associated with PUD, but also with each other $[1,3,12]$. Although the vacuolating cytotoxin is not thought to be a factor that activates neutrophils, it may contribute to activity by some action on the neutrophil cell membrane [12]. The separation of the vacuolating cytotoxin from neutrophil-activating factors may contribute to an overall loss of activity in purified fractions.

\section{References}

1. Rautelin H, Blomberg B, Jarnerot G, Danielsson D. Nonopsonic activation of neutrophils and cytotoxin production by Helicobacter pylori: ulcerogenic markers. Scand J Gastroenterol 1994; 29: 128-132.

2. Nielsen H, Andersen LP. Activation of phagocytes by Helicobacter pylori correlates with the clinical presentation of the gastric infection. Scand J Infect Dis 1995; 27: 347-350.

3. Zhang QB, Nakshabendi IM, Mokhashi MS, Dawodu JB, Gemmel CG, Russell RI. Association of cytotoxin production and neutrophil activation by strains of Helicobacter pylori isolated from patients with peptic ulceration and chronic gastritis. Gut 1996; 38: 841-845.

4. Rautelin H, Sipponen P, Seppälä K, Sarna S, Danielsson D, Kosunen TU. Gastric inflammation and neutrophil-activating and cytotoxin-producing Helicobacter pylori strains. Scand J Gastroenterol 1996; 31: 639-642.

5. Leunk RD, Johnson PT, David BC, Kraft WG, Morgan DR. Cytotoxic activity in broth-culture filtrates of Campylobacter pylori. J Med Microbiol 1988; 26: 93-99.

6. Atherton JC, Cao P, Peek RM, Tummuru MKR, Blaser MJ, Cover TL. Mosaicism in vacuolating cytotoxin alleles of Helicobacter pylori. Association of specific vacA types with cytotoxin production and peptic ulceration. J Biol Chem 1995; 270: $17771-17777$.

7. Xiang Z, Censini S, Beyelli PF et al. Analysis of expression of $\operatorname{cag} A$ and $v a c A$ virulence factors in 43 strains of Helicobacter pylori reveals that clinical isolates can be divided into two major types and that $\operatorname{cag} A$ is not necessary for expression of the vacuolating cytotoxin. Infect Immun 1995; 63: 94-98.

8. Cover TL, Cao P, Murthy UK, Sipple MS, Blaser MJ. Serum neutralizing antibody response to the vacuolating cytotoxin of Helicobacter pylori. J Clin Invest 1992; 90: 913-918.

9. Phadnis SH, Ilver D, Janzon L, Normark S, Westblom TU. Pathological significance and molecular characterization of the vacuolating toxin gene of Helicobacter pylori. Infect Immun 1994; 62: $1557-1565$.

10. Tee W, Lambert JR, Dwyer B. Cytotoxin production by Helicobacter pylori from patients with upper gastrointestinal tract diseases. J Clin Microbiol 1995; 33: 1203-1205.

11. Weel JFL, van der Hulst RWM, Gerrits $\mathrm{Y}$ et al. The interrelationship between cytotoxin-associated gene A, vacuolating cytotoxin, and Helicobacter pylori-related diseases. J Infect Dis 1996; 173: 1171-1175.

12. Leakey A, La Brooy J, Hirst R. The ability of Helicobacter pylori to activate neutrophils is determined by factors other than H. pylori neutrophil-activating protein. J Infect Dis 2000; 182: 1749-1755.

13. Mooney C, Keenan J, Munster D et al. Neutrophil activating by Helicobacter pylori. Gut 1991; 32: 853-857.

14. Craig PM, Territo MC, Karnes WE, Walsh JH. Helicobacter pylori secretes a chemotactic factor for monocytes and neutrophils. Gut 1992; 33: 1020-1023.

15. Mai UEH, Perez-Perez GI, Allen JB, Wahl SM, Blaser MJ, Smith PD. Surface proteins from Helicobacter pylori exhibit chemotactic activity for human leukocytes and are present in gastric mucosa. J Exp Med 1992; 175: 517-525.

16. Nielsen H, Andersen LP. Activating of human phagocytic oxidative metabolism by Helicobacter pylori. Gastroenterology 1992; 103: 1747-1753.

17. Kozol R, McCurdy B, Czanko R. A neutrophil chemotactic factor present in H. pylori but absent in H. mustelae. Dig Dis Sci 1993; 38: 137-141.

18. Norgaard A, Andersen LP, Nielsen H. Neutrophil degranulation by Helicobacter pylori proteins. Gut 1995; 36: 354-357.

19. Rautelin H, Blomberg B, Fredlund H, Järnerot G, Danielsson D. Incidence of Helicobacter pylori strains activating neutrophils in patients with peptic ulcer disease. Gut 1993; 34: 599-603.

20. Mai UEH, Perez-Perez GI, Wahl LM, Wahl SM, Blaser MJ, Smith PD. Soluble surface proteins from Helicobacter pylori activate monocytes/macrophages by lipopolysaccharide-independent mechanism. J Clin Invest 1991; 87: 894-900.

21. Pérez-Pérez GI, Shepherd VL, Morrow JD, Blaser MJ. Activation of human THP-1 cells and rat bone marrow-derived macrophages by Helicobacter pylori lipopolysaccharide. Infect Immun 1995; 63: 1183-1187.

22. Evans DJ, Evans DG, Takemura $\mathrm{T}$ et al. Characterization of a 
Helicobacter pylori neutrophil-activation protein. Infect Immun 1995; 63: 2213-2220.

23. Namavar F, Sparrius M, Veerman ECI, Appelmelk BJ, Vandenbroucke-Grauls CMJE. Neutrophil-activating protein mediates adhesion of Helicobacter pylori to sulfated carbohydrates on high-molecular-weight salivary mucin. Infect Immun 1998; 66: 444-447.

24. Hobson $\mathrm{CH}$, Roberts EC, Broom ME, Mellor DM, Sherriff RM, Chadwick VS. Radio-immunoassay for formyl methionyl leucyl phenylalanine. I. Development and application to assessment of chemotactic peptide production by enteric bacteria. J Gastroenterol Hepatol 1990; 5: 32-37.

25. Van Dervort AL, Lam C, Culpepper S, Tuschil AF, Wesley RA, Danner RL. Interleukin-8 priming of human neutrophils is not associated with persistently altered calcium fluxes but is additive with lipopolysaccharide. J Leukoc Biol 1998; 64:
$511-518$

26. Steck G, Leuthard P, Bürk RR. Detection of basic proteins and low molecular weight peptides in polyacrylamide gels by formaldehyde fixation. Anal Biochem 1980; 107: 21-24.

27. Marasco WA, Phan SH, Krutzch $\mathrm{H}$ et al. Purification and identification of formyl-methionyl-leucyl-phenylalanine as the major peptide neutrophil chemotactic factor produced by Escherichia coli. J Biol Chem 1984; 259: 5430-5439.

28. Broom MF, Mellor DM, Chadwick VS. Purification and amino acid sequencing of naturally occurring $\mathrm{N}$-formyl-methionyl oligopeptides from Escherichia coli. Experientia 1989; 45: 1097-1099.

29. Marasco WA, Showell HJ, Freer RJ, Becker EL. Anti-f MetLeu-Phe: similarities in fine specificity with the formyl peptide chemotaxis receptor of the neutrophil. J Immunol 1982; 128: 956-962. 